\title{
“¿Qué sos, Nicaragua, para dolerme tanto?” Gioconda Belli And The Nicaraguan Cause1
}

\author{
Silvia M. Roca-Martínez \\ The Citadel, The Military College of South Carolina \\ srocamar@citadel.edu
}

DOI: http://doi.org/ 10.36892/ijlls.v3i3.703

\begin{tabular}{|c|c|}
\hline $\begin{array}{l}\text { Received: } \\
\text { 09/09/2021 }\end{array}$ & $\begin{array}{l}\text { Abstract } \\
\text { This article traces Gioconda Belli's trajectory as a writer }\end{array}$ \\
\hline $\begin{array}{l}\text { Accepted: } \\
\text { 28/09/2021 }\end{array}$ & $\begin{array}{l}\text { Nicaraguan Sandinista Revolution, has consistently used her platform as one } \\
\text { of the most renowned contemporary Latin American writers to provide a voice } \\
\text { that transcends national borders to the Nicaraguan cause since the early }\end{array}$ \\
\hline $\begin{array}{l}\text { Keywords: } \\
\text { Nicaragua, feminism, } \\
\text { Sandinismo, } \\
\text { revolution, politics, } \\
\text { literature }\end{array}$ & $\begin{array}{l}\text { 1970s. Through the analysis of some of her most notable works, some of her } \\
\text { contributions in the national and international press, as well as social media } \\
\text { publications, we examine the way her many roles have informed each other } \\
\text { over the years and accomplished a two-fold goal: on the one hand, she has } \\
\text { documented and theorized on the recent history of Nicaragua, in addition to } \\
\text { keeping those in power in check; on the other hand, she has become one of the } \\
\text { foremothers of Nicaraguan feminism. As this article shows, not only has she } \\
\text { crafted - both in writing and action-a roadmap for younger generations of } \\
\text { women, but she has also documented and influenced the evolution of feminism } \\
\text { in Nicaragua. }\end{array}$ \\
\hline
\end{tabular}

\section{INTRODUCTION}

Decades after joining the Sandinista Movement, toppling the Somoza dictatorship, being in the forefront of the Sandinista government, and later severing ties with the Frente Sandinista de Liberación Nacional (Sandinista National Liberation Front; henceforth FSLN), writer, feminist, guerrilla fighter, and political activist Gioconda Belli continues to be one of the loudest and most authoritative voices against Nicaraguan president Daniel Ortega. ${ }^{1}$ One cannot examine Belli's literary work without bringing Nicaragua's recent past into it and, in much the same way, one cannot discuss Nicaragua's recent past without taking into consideration Belli's literary work, feminism, and political activism. Unquestionably, Belli is

\footnotetext{
${ }^{1}$ For over four decades (1936-1979), a dynasty of dictators, the Somozas, ruled Nicaragua with an iron fist. Although their opposition made itself present as early as 1939, the Frente Sandinista de Liberación Nacional constituted the first organized anti-Somoza force (Staten, 2010, p.52). The FSLN was founded in 1960 by Carlos Fonseca, Silvio Mayorga, and Tomás Borge, who were at the time college students, political activists, and former members of the Nicaraguan Communist party. It came to be as a clandestine organization whose goal was to defeat Nicaragua's dictatorship. While organizing both a rural and urban-based guerrilla, the FSLN drew in support from trade unions, youth, and religious organizations. In 1979, the FSLN's efforts came to fruition when they managed to oust the then dictator, Anastasio Somoza Debayle, in what is known as the Sandinista Revolution (Walker \& Wade, 2011, p.40; Randall, 1994, p.19).
} 
one of the trailblazers for feminism in Nicaragua, part and parcel of Nicaragua's recent nation-building processes, and a political activist. Since the early 1970s she has challenged the powers that be in the Central American nation, spoken loudly about iniquitous, international power relations and their effects in Nicaragua, and championed women's rights. Much ink has been spilled on Gioconda Belli's literary career since she published her first poems nearly five decades ago. This impressive body of critical work has examined the Nicaraguan writer's literary production through many prisms that can arguably be divided into three camps: feminism, nation, political activism. Drawing on this critical work, this article seeks to close a gap both by tracing and examining Belli's work as a writer, a feminist, and a political activist as articulated mainly in four of her most celebrated works to date: Sobre la grama (On the Grass) (1972); Linea de fuego (Line of Fire) (1978); La mujer habitada (The Inhabited Woman) (1988); and El país bajo mi piel: Memorias de amor y de guerra (The Country Under my Skin: A Memoir of Love and War) (2001). Particularl, this article explores both the unfolding and development of the symbiotic relationship between Gioconda Belli's literary career and her role as a political activist, feminist, and organic intellectual of the Nicaraguan Sandinista Revolution.

\section{METHODOLOGY}

This is a qualitative study that draws from close readings of a selection of Gioconda Belli's literary work. Moreover, some of her pieces in the press, interviews, and social media posts (Facebook in particular, which over 40,000 people follow) will also be considered.

\section{DISCUSSION}

Gioconda Belli was born in Managua, Nicaragua, on December 9, 1948, into an upper-class family and enjoyed a privileged upbringing. When she was fourteen years old, her parents sent her to Madrid, Spain, to complete her high school education, and later to Philadelphia, United States, to earn her college degree in Marketing and Journalism. Upon her return to Nicaragua, Belli did what any young woman of her age and social status was expected to do: she married at the age of eighteen and had her first daughter when she was nineteen. Shortly after giving birth to her daughter, Belli made her debut in the Nicaraguan literary scene. She published a handful of poems that boldly unveiled topics that had long been considered taboo and did so from a female perspective. Birth, breastfeeding, menstruation, female desire and sexuality, motherhood, and the female body were left in the open and inhabited a space previously reserved for topics that were either discussed from the prism of the male experience, the male desire, and the male gaze, or that were simply entirely neglected. Her work revolutionized Nicaraguan letters.

Although poems like "Y Dios me hizo mujer" ("And God Made Me a Woman") "Menstruación" ("Menstruation"), "Embarazada," ("Pregnant"), or "Quiero" ("I Want") were critically acclaimed and carved her a niche in the Nicaraguan literary scene, they also stroke a cord in the country's high society. In her 2018 book Rebeliones y revelaciones (Rebelions and Revelations), Belli shares with readers the scathing reaction she faced from members of her own family, as well as from her husband at the time, who unsuccessfully forbade her to pursue her writing further (Belli, 2018d, p.38). These first poems would later be part of her first book, Sobre la grama (On the grass) (1972). By revealing the most private physical and emotional aspects of her existence, Belli rebelled against the existing censorship-informed by patriarchal oppression - that enveloped the female experience and suffocated female voices by establishing tacitly accepted, Victorian patterns of conduct. Through her poetic voice, she broke free from the constraints imposed by the societal norms of the time. A revolution was set in motion.

Belli wrote a number of poems that pondered on and revered the physicality and the psychology of being a woman. In addition, readers of Sobre la grama also bore witness to 
Belli's own emerging process of concientización or, in other words, of a growing awareness of the injustice embedded in the social and political spheres. In the poem "Uno no escoge" ("One does not choose"), Belli shares her opinion on what it means to be a citizen and urges readers to act on their responsibility towards their country: "Uno no puede evadir su responsabilidad" ("One cannot evade one's responsibility"), she states (Belli, 1972, p.115). ${ }^{2}$ Everyone, the poem claims, has the responsibility to help build the place that future generations will inhabit. This poem reveals the author's own sense of civic responsibility and aims at inspiring it in others. "Uno no escoge" is part of a collection of poems that, almost in its totality, documents a Nicaraguan woman's rejection of a stale idea of womanhood that stifles her, as well as the crafting of a new one that is her own. This new conception of womanhood is at odds with the societal norms of the time and is far from gratuitous. On the contrary, it points towards a revolution that unfolds from within, on a very personal level, and that later transcends the self to become a collective experience. It is in fact an accurate illustration of feminism as a revolutionary process. The new society that Belli envisions starts in every single Nicaraguan, where an act of love and care for the community-in this case, understood as the Nicaraguan nation-derives from an act of self-discovery, self-love, and self-care. Sobre la grama, therefore, constitutes the feminist manifesto of a young woman and poet who sets out to rewrite and reinscribe herself, as well as her self-perception and selfpositioning, in society. While doing so, she discovers, exposes, and projects her own political power. Owning her body and her sense of self propels Belli to partake in Nicaragua's plight for freedom.

As Belli's involvement with the FSLN intensifies, ultimately forcing her into exile to Mexico and Costa Rica, so does the presence of militancy in her poetry. This presence illustrates what her fellow-Nicaraguan poet Daisy Zamora rightly claims: "la poesía fue, pues, para algunas mujeres, un acceso a la participación revolucionaria y al mismo tiempo un producto literario, verbalmente revolucionario" (Zamora, 1992, p.934-35). ${ }^{3}$ Belli's second book of poems, Línea de fuego, which earned her the prestigious Casa de las Américas literary award, illustrates this shift, which can be appreciated from the book's dedication: "A mis compañeros del Frente Sandinista de Liberación Nacional" ("To my comrades in the

Sandinista National Liberation Front" (Belli, 1978, p.7). Línea de fuego illustrates how Belli acted on her own musings on civic duty that she laid out in her poem "Uno no escoge" ("One does not choose"). She did not shy away from what she understood as her responsibility as a citizen; instead, she took it on. Unlike Sobre la grama, which the author dedicated to Maryam and Melissa-her only two children at the time-, Linea de fuego is a book crafted

2 "Uno no escoge el país donde nace;/ pero ama el país donde ha nacido./ Uno no escoge el tiempo para venir al mundo; pero debe dejar huella de su tiempo;/ Nadie puede evadir su responsabilidad./ Nadie puede taparse los ojos, los oídos,/ enmudecer y cortarse las manos./ Todos tenemos un deber de amor que cumplir,/ una historia que nacer/ una meta que alcanzar./ No escogimos el momento para venir al mundo:/ Ahora podemos hacer el mundo/ en qué nacerá y crecerá/ la semilla que trajimos con nosotros." "“We do not choose the country where we were born;/ but we love the country where we were born./ We do not choose the time in which we come into this world; but we must leave our mark therein;/ We can't evade our responsibility./ We can't cover our eyes, our ears,/ loose our voice and cut out our hands./ We all have a duty of love that we must fulfill,/ a story to give birth to/ a goal to reach./ We did not choose the time to come into this world;/ now we can create the world /in which the seed that we brought with us will germinate and grow.") (Belli, 1972, p.115). 3 "For some women, writing poetry fulfilled a twofold purpose: It was a way of participating in the Revolution, as well as a way of creating literature that was revolutionary." 
by an urban guerrillera, a FSLN militant, a woman fully devoted to the Nicaraguan cause. As the following passage of the poem "Hasta que seamos libres" ("Until we become free") illustrates, by that point, Belli, Nicaragua, and the Nicaraguan plight had become one:

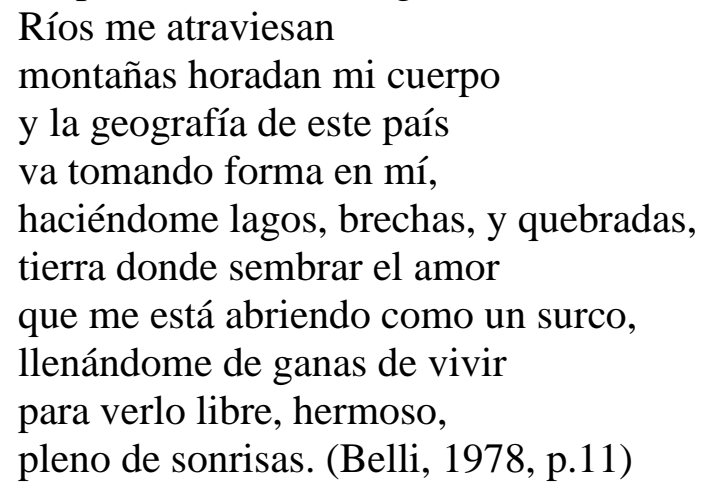

As this poem suggests, Nicaragua and the female body, in this case Belli's, stand as one and the same battleground. Unsurprisingly, the entire book revolves around the author's experience as a FSLN militant woman. In the poem "Ya van meses, hijita," ("It's been months, my child") motherhood is depicted as experienced in exile, separated from her young daughter (Belli, 1978, p.36). Birthing a new nation calls for a steep sacrifice: being away from your own child. The poem "Engendraremos niños" ("We will conceive children") portrays both motherhood and the sexual act as revolutionary endeavors, geared towards defeating the enemy. It reinscribes procreation, pregnancy, and the act of giving birth within a new order: these otherwise biological facts of life that have traditionally operated from within a patriarchal framework are now reframed as rebellious acts, as a form of social activism that strives to offset the assassinations of dissenters by the Somoza dictatorship (Belli, 1978, p.37).

Notwithstanding, if we were to name an overarching theme in this book, it would be love. Time and again, the poet signals at love as the catalyst for the turn her life took as well as for the ethos of a new type of leadership. In each poem, Belli lays out the personal toll it took to love Nicaragua as unconditionally as she did/does: living in exile, not seeing her daughters during months at a time, being in a romantic relationship with a fellow-FSLN militant while feeling death hovering over their shoulders, and being constantly watched and threatened by the Somoza police, among other intense life experiences. In sum, giving up any sense of normalcy, any ties to her former privileged life. For instance, in "Vivo en Costa Rica" ("I live in Costa Rica"), Belli explains the nature of her exile in a few words:

Vivo en Costa Rica

condenada al destierro

y a dieciocho meses de cárcel

por haber amado

más de la cuenta. (Belli, 1978, p.18)

This short poem points at exile and a prison sentence as direct consequences of love. Although the object of this love is not overtly revealed therein, it can be inferred from the book that the poem alludes to Nicaragua. Belli's unconditional love for her country acts as a catalyst that makes her triage out everything else in her life; namely, motherhood, literary success, and even residing in the very same country for which she fights. Her love for Nicaragua seems to be a priority over her love for her family, her class privilege, as well as any sense of normalcy in her life. By writing about love, instead of writing explicitly about politics or the guerrilla movement, for instance, Belli was able to shift a guerrilla war

4 "I live in Costa Rica/ sentenced to exile/and to eighteen months in prison/ for having loved/ way too much." 
narrative that was almost exclusively masculinist in tone, perception, and action into a more personal, relatable, and universal one.

In the 1980s, Belli decides to devote herself full-time into her writing career and embark on her first novel. La mujer habitada (The Inhabited Woman) - a highly autobiographical work that catapulted her into the international literary scene-was published in 1988. In this novel, Belli both exposes and examines the issues with which she had to contend as a woman and as an active FSLN militant such as sexism within the organization, impostor syndrome, and her efforts to advance women's rights in a society that had changed leadership but that continued to cling to stale values. The novel also addresses the struggles of a young, professional woman who is also part of a clandestine political organization. The main character, based loosely on Belli herself, embodies the predicament the new Nicaraguan woman faces: learning to navigate the demands of a society that she is helping build, while ironically dealing with constraining, patriarchal gender norms. Although Somozism was dead, patriarchy lived on regardless of political affiliations, which proved that the revolution had to happen simultaneously on many fronts.

La mujer habitada tells the story of Lavinia, a young, bourgeois woman from the fictional Faguas - read Nicaragua-, who, upon returning from pursuing her education overseas, gets a job as an architect at a firm and moves away from her family home. Lavinia's life takes an unexpected turn when she becomes acquainted with a colleague, Felipe, who later becomes a romantic interest and who happens to be involved with the FSLN. During an episode in which Felipe seeks her help, she meets two other militants, Sebastián and Flor. This incident drives her to educate herself about the clandestine organization, which in turn eventually drives her to join in. Lavinia's process of concientización (awareness raising) begins soon thereafter, and she begins to perceive the reality around her through a much different prism:

Un niño descalzo con pantalones remendados vino corriendo hasta su automóvil. "Le cuidé el carro"—-dijo, extendiendo su mano. Lavinia sacó unas cuantas monedas y se las dio . . " "Tal vez tendrá la oportunidad de ser médico o abogado," pensó Lavinia, acomodando esta imagen junto a las otras. No entendía claramente qué le estaba ocurriendo. La calle entera daba gritos, el paisaje se transformaba. Todo eso, aquel estado de cosas había estado allí desde que era niña, ella siempre lo había visto. (Belli, 2006, p.157)

Through her newly acquired sense of concientización, Lavinia truly starts seeing the reality around her. No longer desensitized to poverty, injustice, or inequality, she experiences the vertigo of learning to see the world around her as it was experienced by others less privileged than her. Her life becomes even more convoluted upon joining the FSLN-not only does she start living a double life, but she is also confronted with the limitations of her roles as a woman and an engaged citizen. Being an active militant empowers her, since it affords her the opportunity to improve the lives of her fellow Nicaraguans; however, as it was, the FSLN subjugated her newly found feminism, social conscience, and political activism to an organization that rested both on a hierarchical and a masculinist chain of command. In a scene from the novel, a captain who had opposed the dictatorship is assassinated after doing time in prison; the people from Faguas rally to attend his funeral and

\footnotetext{
5 "'A barefoot boy with patched pants came running to her car. 'I watched your car for you,' he said, holding out his hand. Lavinia took out a few coins and gave them to him . . 'Maybe he'll have the chance to be a doctor or a lawyer,' Lavinia thought, fitting this image among the others. She didn't understand clearly what was happening to her. The whole street was shouting at her, the landscape was being transformed. It had all been there since she was a little girl, she thought: this state of things. She had always seen it" (Belli, 2004, p.187).
} 
show their discontent. Lavinia initially plans to attend the funeral, but the FSLN tells her otherwise. After questioning the orders, Lavinia, reluctantly, complies. What follows is one of the first instances in which she puts her own judgment and agency aside to comply with the FSLN's orders: “-Esto es frustrante-dijo, desmadejando el cuerpo en la silla-. Yo pensaba que mi vida cambiaría radicalmente... que podría participar, no quedarme al margen como siempre... Se quedó al margen como siempre, con Sara y Adrián” (Belli, 2004, p.174). ${ }^{6}$ As this fragment makes abundantly clear, belonging to a political organization, despite its progressive political and social goals, was not tantamount to achieving a sense of freedom or empowerment. Lavinia is an educated woman who manages to carve a space for herself in a heavily-dominated male profession. She also supports herself and lives on her own. Nevertheless, despite her success in breaking free from several societal conventions, and to free her country and her fellow countrymen and women from a brutal dictator, Lavinia ironically finds herself collaborating with an organization that restricts her freedom and demands that she obey orders.

In the tradition of magical realism, Lavinia is closely watched and encouraged by the spirit of Itzá, a former indigenous woman who fought the Spaniards during the early colonial period and who now lives on in the form of an orange tree in Lavinia's backyard. Itzá, the novel elaborates, fought alongside the men of her tribe against the Spaniards and joined the efforts of many indigenous women who refused to engage in sex with their partners to prevent getting pregnant and thus provide Spaniards with more indigenous population to use at their convenience (Belli, 2004, p.120-21). Through Itzá, Belli makes a compelling argument about the long history of injustice and the connections between the inequity spawned by colonization and imperialism - first by Spain and later by the United States - and Nicaragua's social and political shortcomings. Through these fictional characters, the author also underlines the important role Nicaraguan women have had in fighting back throughout history. As Socorro León and Magdalena Vengas rightly state, "La mujer habitada es un enfrentamiento con las estructuras patriarcales, es un cuestionamiento constante a través de Lavinia, sobre el papel que desempeña la mujer en nuestras sociedades" (León \& Vengas, 1998, p.63) ${ }^{7}$ - a subject that Belli knows all too well.

In 2001, a few novels and books of poetry later-all of which explore the role of women in defying society's gender norms and society's grand narratives-, Gioconda Belli published her only memoir to date, El país bajo mi piel: Memorias de amor y de guerra (The Country Under My Skin: A Memoir of Love and War; henceforth El país). Belli's life had significantly changed since she published La mujer habitada. By the early 2000s, she was already a renowned author, had spent a decade in the US, and had severed ties with the FSLN. Furthermore, Belli had founded, alongside other former key FSLN figures such as former Nicaraguan vice-president Sergio Ramírez and former Nicaraguan Secretary of Culture Ernesto Cardenal, the Movimiento Renovador Sandinista (The Sandinista Renovation Movement) and had started a campaign to discredit Daniel and Humberto Ortega, who they blamed for appropriating the FSLN and divesting it of its original ethos and mission. The writers and political activists involved in the Movimiento Renovador Sandinista have also attempted to discredit Nicaragua's alleged fraudulent political system. In 2001, in the months leading up to Nicaragua's presidential elections, Belli, Ramírez, and Cardenal issued several press releases in which they expressed their refusal to cast their votes in what they considered

6 “"'This is frustrating,' she said, slumping into a chair. 'I thought my life would be radically changed... that I could participate, not find myself on the sidelines as always.' . . . She remained in the periphery with Sara and Adrián" (Belli, 2004, p.208).

7 "The Inhabited Woman constitutes a rebuttal of patriarchal structures. Through its main character, Lavinia, it constantly questions the role women play in our societies." 
to be a country with corrupt politics and politicians (Cardenal, Belli, \& Ramírez, 2001, n/p). Their campaign remains active to date despite Cardenal's death on March 1, 2020.

Belli's memoir was published a little over two decades after the Sandinista Revolution toppled the Somoza dictatorship. The $20^{\text {th }}$ anniversary of the revolution, on 1999, also spawned some introspection in other former FSLN members: Sergio Ramírez's memoir Adiós muchachos: Una memoria de la revolución Sandinista (Adiós Muchachos: A Memoir of the Sandinista Revolution) and Ernesto Cardenal's Vida Perdida (Lost Life) were published in 1999. In El país, Belli takes stock of her life as well as of the life of the FSLN, and the events that befell Nicaragua during her adult life. She crafts her memoir from the vantage point of a much wiser and much less idealistic woman who looks back and ponders on her own journey and that of the nation she helped shape. She has gained perspective throughout the years, a perspective that she still lacked during the time she wrote La mujer habitada. During that time, the Sandinista Revolution was still ongoing, and Belli was an active member of the FSLN, with neither disillusionment nor a high degree of introspection looming yet in her horizon. The idealism that is present in Linea de fuego or La mujer habitada, for instance, took a back seat in El país. Disillusion, introspection, and, at times nostalgia are the engines that propel the narration of the memoir. Nonetheless, the opening sentence leaves no room for doubt as to what are the two overarching yet interwoven themes in the memoir: gender and nation: "Dos cosas que no decidí decidieron mi vida: el país donde nací y el sexo con el que vine al mundo" (Belli, 2003a, p. 11). ${ }^{8}$ Belli shares episodes of her life since childhood until 2001 not only through a gendered lens - which we can appreciate in all of her work-, but also through the lens of time. In El país one can recognize a broader, wiser, perspective, sustained by Belli's experience and temporal distance from the events and experiences she narrates.

One of the ways in which Belli chooses to address gender is by appropriating the quintessential novel of Hispanic letters, El ingenioso Hidalgo Don Quijote de la Mancha (1605), by Miguel de Cervantes Saavedra. Throughout the memoir, Belli calls herself a Quijota (a female Don Quixote). Furthermore, she also structures her memoir in chapters that are introduced by titles that provide readers with a hint about their content - for example, "Donde dan inicio, con olor a pólvora, estas rememoraciones"9 (Belli, 2003a, p.15)—, which is exactly how Cervantes' novel is structured. This purposeful self-identification with the character of Don Quijote - an idealistic, old man consumed by tales of heroic knights who aims to right all wrongs and fight injustice and who is madly in love with an imaginary woman-assists Belli in depicting herself as a naïve, idealist young woman or, in her own words, as "una muchachita burguesa vestida a lo hippie"10 (Belli, 2003a, p.47), who became fully invested in the Nicaraguan cause and joined the now ill-reputed FSLN. This identification trope also assists her in depicting the idealism that led her to join the FSLN and the disillusionment that later made her sever ties with it. In El país, Belli crafts a narrative of her life that inspires empathy instead of judgment on the part of readers. She does not blame the Nicaraguan political debacle on the revolution itself, but instead, she points the finger at its leaders. As she claims, she was not disappointed with the Revolution per se, "me desilusionaban sus dirigentes"11 (Belli, 2003a, p.383), later adding that her love for the

\footnotetext{
8 "Two things decided my life: my country and my sex" (Belli, 2003b, p.ix)

9 "Where these memories, dusted with gunpowder, begin" (Belli, 2003b, p.3).

10 "A bourgeois young woman dressed like a hippie" (Belli, 2003b, p.73).

11 "I was not disappointed with the Revolution, I was disappointed with its leaders." (My translation; this sentence appears in the original Spanish version but not in its English translation. The closest sentence found in the English version reads as follows: "At the beginning of 1984 I had begun to question the wisdom of the Sandinista leadership" (Belli, 2003b, p.311).
} 
Revolution "no era ciego, pero era tolerante e incondicional"12 (Belli, 2003a, p.384). Thus, loosely speaking, the Revolution was to Belli what the books of chivalry were to Don Quixote.

The importance of gender and the defiance of gender norms is apparent even before opening the memoir: the cover of the first edition, published by Vintage Español in 2001, shows a young woman-presumably a young Belli-wearing a t-shirt, cargo pants, and heels. She is also wielding a machine gun. As I have discussed elsewhere, this image alone defies the image of the quintessential Latin American guerrilla fighter embodied by Ernesto "Che" Guevara. ${ }^{13}$ In his published diaries and, by and large, in nowadays' well-known images of Che Guevara, one sees a stern, bearded, and manly man, sometimes wielding a gun, some other times smoking a cigar-both of them phallic symbols that denote power and sensuality. The picture of Belli that appears in the book cover challenges what Ileana Rodríguez calls a masculinist account of Latin American revolutions and guerrillas that neglects and marginalizes women (Rodríguez, 1996, p.xv). However, Belli challenges the guerrillero figure even further by pointing at the flaws of a gender hierarchy that has traditionally both romanticized and exoticized Latin American male revolutionaries and which has simultaneously long prevented honest discussions on the shortcomings of both said construct and its ramifications. One of the ways in which Belli does so is by pointing at the lack of selfexamination, as well as at a flawed notion of the idea of a revolution that allowed FSLN male militants to continue to uphold masculinist practices that relegated their fellow FSLN militant women, such as herself, to the role of emergency support personnel of sorts and therefore, in many cases, to invisibility. A case in point is Belli's description of what she witnessed at the FSLN's headquarters soon after toppling Somoza: women executing tasks traditionally assigned to women, such as secretarial work, food preparation, and food serving (Belli, 2003a, p.331). Belli's memoir calls into question the leadership skills of revolutionaries who fail to bring gender equality from theory to practice and ponders on the intoxicating effects of power. Ultimately, El país advocates for a renewed kind of leadership, one that delivers to a citizenry other than the cisgender, heterosexual, upper-class men and is therefore feminist at its core.

Since April 2018, Nicaragua has yet again occupied central stage in world news as civil unrest has taken the streets to protest President Ortega's unpopular economic and social reforms; the death toll continues to rise as Ortega confronts both dissent and discontent with state violence. Nicaraguans from all walks of life are speaking up against a president, who is also the leader of the FSLN, and a system that do not longer serve them. Belli continues to be one of the most respected intellectuals to provide the Nicaraguan cause, an international platform, a voice. In addition to being a very prolific writer whose work has been translated to more than twenty languages and recognized with countless awards, she also maintains a very public profile via social media, opinion pieces, and interviews in different media outlets. ${ }^{14}$ She devotes both her public profile, which rests on her symbolic capital, to calling international attention to Nicaragua. On April 4, 2018, for instance, in an interview for the German television outlet DW, shortly after the revolts started, she publicly asked President Ortega to resign his position and allow a rebirth of democracy in Nicaragua through, among

\footnotetext{
12 "My love wasn't blind, but it was tolerant and unconditional" (Belli, 2003b, p.312).

${ }^{13}$ Roca-Martínez, 2016, pp. 37-52.

${ }^{14}$ To date, Gioconda Belli has published nine books of poetry, eight novels, one memoir, and a collection of essays, in addition to countless opinion pieces published in national and international newspapers. In 2018, she received the Hermann Kesten Prize, for defending freedom of speech, from the hands of the German PEN Center. In October 2018, Festival Eñe chose her as the recipient of the Lifetime Literary Achievement Award. In 2019, she was the recipient of the 2019 Oxfam Novid/PEN International award for Freedom of Expression.
} 
other means, peaceful and transparent presidential elections (Belli, 2018a, n/p). ${ }^{15}$ She has also turned her Facebook wall, a public site with more than 40,000 followers to which anyone has access, into a thorough source of news, videos, and personal narratives that bear witness to the events that have recently befallen Nicaragua. On September 7, 2018, in an interview to Uruguayan newspaper El País, Belli articulated her position regarding her role as a writer, as a citizen, and as a political activist. She asserted her role as Nicaragua's voice:

Lo que yo les digo a mis hermanos nicas lo digo en mis poemas, en mis artículos. Estoy obsesionada con tratar de contar lo que está pasando. Eso es lo que hago: hablar, hablar y hablar. Creo en las palabras y los escritores tenemos la obligación de poner en palabras lo que mucha gente tal vez siente, pero no lo puede poner en palabras. Y para mí esto es una lucha importantísima, porque Nicaragua se merece un mejor futuro, la libertad por la que ha muerto tantísima gente. Eso es lo que hay que decirles a los jóvenes, ellos deben tomar esta parte de la historia en sus manos y confío en que van a ser mejores que nosotros. (Belli, 2018c, n/p) $)^{16}$

As her words suggest, Belli sets no boundaries between her literary work and her political activism: The Nicaraguan cause informs her writing, and she deems herself responsible for giving Nicaraguans a voice. On the upcoming $42^{\text {nd }}$ anniversary of the Nicaraguan Revolution, she published an opinion piece in the Spanish newspaper El País, which she also shared in her Facebook wall, in which she deems the Nicaraguan Revolution defunct and bemoans the many lives lost along the way just to end up with yet another tyrannical figure in power. (Belli, 2018b, n/p.) ${ }^{17}$ Despite being aware of the repercussions that her defiance toward Daniel Ortega's government can afford her, both her love for Nicaragua and her self-assumed civic duty compel her to continue being openly critical. ${ }^{18}$ Belli refuses to be silent.

\section{CONCLUSION}

Since early on in her career, in Sobre la grama (On the grass), Belli suggests that the revolution starts from within each person. It is a personal transformational process that later becomes collective. In her poems, she weaponizes her experiences as a woman to defy patriarchy. In this book of poems, the reader can appreciate the birth of her awareness rising. In Linea de fuego (Line of Fire), her commitment to the FSLN is unwavering. Her personal revolution has transcended the private sphere. Her perspective is that of a militant woman, fully devoted to a cause. The revolution has now become a collective experience for which she is willing to make sacrifices. Most importantly, this collection of poems places love-

\footnotetext{
15"We want Ortega to retire."

16 "What I tell my fellow-country men I also say in my poems and in my articles. I am obsessed with telling what is happening in Nicaragua. This is what I do: talk, talk, and talk some more. I believe in words and we writers have the obligation to put into words what many people may be feeling but can't. For me this is an extremely important fight, because Nicaragua deserves a better future and the freedom for which so many people gave up their lives. This is what we need to tell our youth, they must take up the torch and I trust they will be better than us."

17 "Revolution met its death in Nicaragua."

${ }^{18}$ The dangers of being critical against Ortega's government have in fact materialized for fellow Nicaraguan writer Sergio Ramírez. Upon the publication of his newest novel, Tongolele no sabia bailar (Tongolele did not know how to dance) (2021), in which he examines the 2018 uprising, Ortega has issued a warrant for his arrest and seized copies of the novel.
} 
rather than hate, vengeance, honor, masculinity, or power, for instance - at the center of her involvement with the FSLN. Ten years later, Belli would publish her first novel, La mujer habitada (The Inhabited Woman), a fictionalized account of her experience as a FSLN militant woman. Although at that point in time, Belli was still very much a part of the FSLN - the then legitimate political party elected to power by the Nicaraguan people-, Lavinia's story reveals some discontent with the masculinist ways from which the FSLN does not seem (wish?) to break free. This novel begs us to ask the following question: how revolutionary can a revolution be if its leadership does not stand behind some of the muchneeded changes? The novel suggests that idealism and self-introspection are not only not incompatible, but necessary. Finally, the publication of her memoir, shortly after Sandinista Revolution's twentieth anniversary, marked yet another shift in her literary and political trajectories. In this new literary project, Belli takes stock of her life. Perhaps most importantly, she takes stock of the mistakes made by the Revolution and by her, and criticizes its leaders harshly. El país constitutes the manifesto of a disillusioned, matured woman who uses her symbolic capital to effect a change in the new nation she helped birthed. It's the result of great introspection that marks the end of an era that witnessed the rise of the revolutionary left in Latin America.

After a lifetime devoted to both feminism and the Nicaraguan cause, Gioconda Belli swells the ranks of Latin American women who have challenged power structures in their respective countries and thus have contributed to the improvement-notwithstanding setbacks - and visibility of their geopolitical region. Her literary career and political activism speak to a life committed to one cause, the Nicaraguan cause, which, as shown, she has also decentered from its masculinist aura and rearticulated in more inclusive terms. Through her literary work and her political activism, she has helped shape and document the recent history of Nicaragua. Belli has never ceased to be a much-needed critical voice throughout this process; she has relentlessly pointed the finger and criticized a masculinist model of leadership that has yielded poor results in the region, as Daniel Ortega's new rise and claim to power shows. In turn, she has vindicated a more holistic and feminist model of leadership based on true equality, introspection, self-criticism, and accountability. Belli's life and work attest to the important role of women in the public sphere on both a national and an international level as well as defies misconceptions that render women in underdeveloped, conflict-ridden, countries as powerless victims.

\section{REFERENCES}

Belli, Gioconda. (1978). Línea de fuego. Casa de las Américas.

Belli, Gioconda. (2003a). El país bajo mi piel: Memorias de amor y de guerra. Vintage Español. (Original work published in 2001 by Plaza \& Janés).

Belli, Gioconda. (2003b). The Country Under my Skin: A Memoir of Love and War. (Kristina Cordero and Gioconda Belli, Trans.). Anchor Books. (Original work published in 2001).

Belli, Gioconda. (2004). The Inhabited Woman. (Kathleen March, Trans.). University of Wisconsin Press. (Original work published in 1988).

Belli, Gioconda. (2006). La mujer habitada. Seix Barral (Original work published in 1988).

Belli, Gioconda. (2014). Sobre la grama. Navona. (Original work published in 1972). 
Belli, Gioconda. (2018a, June 4). Queremos que Ortega se retire. DW Noticias. https://www.dw.com/es/gioconda-belli-queremos-que-ortega-se-retire/av-44074467.

Belli, Gioconda. (2018b, September 4). Dios mío! Ahora estos chavalos secuestrados hoy!! Picture of the three kidpnapped youth attached. Facebook. www.facebook.com/gioconda.belli/posts/10156256682443961

Belli, Gioconda. (2018c, September 7). Están matando sin piedad. El País. https://www.elpais.com.uy/cultural/matando-piedad.html.

Belli, Gioconda. (2018d). Rebeliones y revelaciones. Txalaparta.

Belli, Gioconda. (2021, June 25). En Nicaragua no hay más revolución. El País. https://elpais.com/opinion/2021-06-26/en-nicaragua-no-hay-masrevolucion.html?fbclid=IwAR09XwLdigDZRBdPOJ7fo9IT9A1czG_eitK5jTgGDtBB qfGtetzdnblWdos.

Cardenal, Ernesto. (1999). Memorias: Vida perdida. Anamá.

Cardenal, Ernesto, Belli, Gioconda, \& Ramírez, Sergio. (2001, October 10). No votaremos. El Nuevo Diario. https:// www.lainisgnia.org/2001/octubre/ibe_035.htm.

León, Socorro, \& Vengas, Magdalena. (1998). Desmitificación del texto patriarcal en La mujer habitada. Revista de Filología y Lingüística de la Universidad de Costa Rica, 24(2), 61-76.

Randall, Margaret. (1994) Sandino's Daughters Revisited: Feminism in Nicaragua. RutgersUniversity Press.

Roca-Martínez, Silvia M. (2016). Genre, Gender, and the Translation of Latin America:A Reevaluation of Memoirs of Latina American Women Intellectuals. In Patricia Bolaños-Febres, Tania Gómez, \& Christina Mougoyanni Hennessy (Eds.), Gender in Hispanic Literature and Visual Arts (pp. 37-52). Lexington Books.

Rodríguez, Ileana. (1996). Women, Guerrillas, and Love: Understanding War in Central America. University of Minnesota Press.

Staten, Clifford L. (2010). The History of Nicaragua. Greenwood.

Zamora, Daisy. (1992). La mujer nicaragüense en la poesía. Antología. Nueva Nicaragua.

Walker, Thomas W. \& Wade, Christine J. (2011). Nicaragua: Living in the Shadow of the Eagle. Westview.

\section{AUTHOR'S BIO}

Dr. Roca-Martinez is Associate Professor of Spanish at The Citadel, The Military College of South Carolina (Charleston, South Carolina, United States). She has published articles in journals such as Chasqui, A Contracorriente or Cincinnati Romance Review and and has been a contributor in several edited volumes on Latin American literature, film, and culture. 